\title{
The Influence of Online Learning and School Communication With Students to Improving Student Achievement
}

\author{
Widyanti $^{1}$, Yahya Sudarya ${ }^{2}$, Bakhtiar Yusup ${ }^{3}$, Retno Purwaningsih ${ }^{4}$ \\ $\left\{\right.$ widyanti02@gmail.com ${ }^{1}$, yahyasudarya@yahoo.com ${ }^{2}$, bakhtiaryusup12@gmail.com $^{3}$, \\ retnopurwaningsih160679@gmail.com ${ }^{4}$ \} \\ ${ }^{1}$ SDN Kutawaru 01 Cilacap \\ ${ }^{2}$ Magister Pendidikan Dasar, Universitas Muhammadiyah Purwokerto \\ ${ }^{3}$ SMP Muhammadiyah 1 Purwokerto \\ ${ }^{4}$ SD Negeri Sawangan 02 Cilacap
}

\begin{abstract}
This research is motivated by a change in the learning paradigm caused by the Covid-19 Pandemic, learning that was previously carried out conventionally in the classroom has turned into Online learning which is technically and culturally very different from before. This study aims to determine the effect of online learning and school communication on improving student achievement in science subjects in Cilacap Tengah Sub- district State Elementary School, Cilacap Regency. The study was conducted using a survey research type with a population of all teachers in 25 State Elementary Schools in Cilacap Tengah District, Cilacap Regency. The sampling technique used was saturated sampling technique, consist of all elementary state in Cilacap Tengah District, Cilacap Regency. The research subjects were teachers and principals who taught at elementary state of Cilacap Tengah District Cilacap Regency that consisting of teachers and school principals with a total of 75 respondents. Data analysis used descriptive qualitative analysis methods, normality test, linearity test and multiple regression. The results showed that there was an effect of online learning on the improvement of learning achievement in science learning in Cilacap Tengah District elementary state, Cilacap Regency. 2) There is an influence of teacher and student communication on the improvement of learning achievement in science learning in Cilacap Tengah District Elementary state,Cilacap Regency.
\end{abstract}

Keywords: Online Learning, School Communication, Learning Achievement, Elementary School

\section{Introduction}

The implementation of learning by utilizing online media in Indonesia is supported by the issuance of Regulation of the Minister of Education and Culture Number 68 of 2014 concerning the role of educators and ICT educators on Computer Skills and Information Management in the implementation of the 2013 curriculum. Teachers as educators are also required to have a professional duty to develop teaching competencies with the latest developments in science and technology in carrying out classroom learning in accordance with Law No. 14 of 2005 on teachers and lecturers. In addition there is Regulation of the Minister of Education No. 16 of 2007 concerning Academic Qualification and Educator Competency standards that the pedagogical competency standards of Elementary School/MI teachers are able to utilize information and communication technology for the benefit of learning. 
Pane \& Dasopang explain that learning is said to be the process of providing guidance or assistance to students in carrying out the learning process [1]. In the learning process, it is always marked by the interaction between teachers and students. These interactions are carried out to achieve the goals that must be achieved. Meanwhile, according to Bilfaqih \& Qomarudin, online learning is a program of organizing online learning classes to reach a massive and broad target group[2]. Online learning is learning that uses multimedia technology, virtual classes, CD, ROM, video streaming, voice training, email and conference calls, animated online text and online video streaming [2].

Ghirardini explains that online provides effective learning methods, such as practicing with related feedback, combining collaborative activities with independent learning, personalizing learning based on student needs and using simulations and games [3]. Meanwhile, according to Permendikbud No.109/2013 distance education is a teaching and learning process that is carried out remotely through the use of various communication media. Based on understanding above, it can be concluded that online learning is something that utilizes technology using the internet where in the learning process it is not done face to face but uses electronic media which can make it easier for students to learn anytime and anywhere.

Rogers (in Mulyana) stated communication is a process where an idea is transferred from a source to one or more recipients, with the intention of changing their behavior [4]. So in general, communication can be defined as an effort to deliver messages between humans. So, the science of communication is the study of the delivery of messages between humans, the object of communication is communication, that is delivery of messages between humans [5].

The communication process is the process of conveying thoughts or feelings by someone (communicator) to others (communicant). Thoughts can be ideas, information, opinions, etc., which arise from his mind. Feelings can be in the form of confidence, certainty, doubt, worry, anger, courage, etc. that arise from the bottom of the heart. Essentially, teaching and learning activities are a communication process.

The communication process (the process of delivering messages) must be created, realized through the delivery and exchange of messages or information by every teacher and student [6]. Educational communication is an aspect of communication in the world of education or communication that occurs in the field of education. This communication takes place in a free, intimate and purposeful (also responsible) atmosphere. Here communication takes place without coercion, each party freely and without pressure to express their ideas and feelings to others. What is meant by educational communication is communication that has a specific purpose, that is to mature human children [7].

To develop students' talent and potential, so the teachers and students must establish a communication in learning activities [8]. During the learning process, teachers can find out the potential of their students. Communication between teachers and students must be well established as long as students study in that place. Teachers and students are a scope that cannot be separated. In distance learning, communication can be done through online learning. Based on this, in online learning the teacher must have a good communication strategy so that students' learning achievement is maintained properly [7].

\section{Method}

This research is a survey research with a quantitative research approach. The population in this study were state elementary students in Cilacap Tengah District, Cilacap Regency who came from 25 elementary school. The samples taken in this research were 75 respondents. The subjects in this study were teachers and principals who teach at State elementary school of Cilacap Tengah District in Cilacap Regency. The independent variable in this study is Online 
Learning $\left(\mathrm{X}_{1}\right)$, School Communication $\left(\mathrm{X}_{2}\right)$ while the dependent variable is Learning Achievement (Y). The data collected in this study are in the form of Online Learning score data, School Communication and Learning Achievement Value. The data collection technique was done by: (1) questionnaire; (2) recording documents, and (3) summative test scores. After that, the validity test, reliability test, normality test, linearity test, and regression test were carried out. Analysis was performed on all data obtained.

\section{Result and Discussion}

Table 1. Normality Test Result One-Sample Kolmogorov-Smirnov Test

\begin{tabular}{lrrr}
\hline & Online Learning & Communication & $\begin{array}{c}\text { Learning } \\
\text { Achievement }\end{array}$ \\
\hline $\mathrm{N}$ & & 75 & 75 \\
Asymp. Sig. (2-tailed) & .697 & .280 & .775 \\
\hline
\end{tabular}

a. Test distribution is Normal.

Based on the table above, it is known that the sig value for online learning (0.697), communication between teachers and students (0.280), and the sig value of learning achievement $(0.775)$ is greater than 0.05 , this indicates that the data is normally distributed, i.e. the distribution of data that can represent the population. so that it can be continued with parametric statistical analysis.

Table 2. Results of the Linearity Test of the Online Learning Variable and Teacher-Student Communication Variable on the Learning Achievement Variable

\begin{tabular}{lcccc}
\hline \multicolumn{1}{c}{ Keterangan } & Sig & B & t-test/sig & $\begin{array}{c}\text { Adjusted R } \\
\text { Square }\end{array}$ \\
\hline Online Learning * Learning achievement & .078 & - & $3.244 / 0,002$ & \\
Communication * Learning achievement & .238 & - & $2.136 / 0.036$ & 0.182 \\
Constant) & - & 38.21 & & \\
Online Learning & - & 7 & & \\
Communication & - & .389 & & \\
\hline
\end{tabular}

The results of the Linearity Test of the Online Learning variable (X1) on the Learning Achievement variable (Y), it is known that the $\mathrm{p}$ value ( $\mathrm{sig}$ ) is 0.078 which is greater than 0.05 , this indicates that the variable Online Learning on Learning Achievement (X1) has a linear relationship. The results of the Linearity Test of the Teacher Communication with Online Students variable (X2) on the School Achievement variable (Y) note that the p value (sig) is 0.238 which is greater than 0.05 , this indicates that the variable Teacher-Student Communication on School Achievement (X2) there is a linear relationship. 
Based on the results of the multiple regression analysis above, the regression equation can be drawn up as follows:

$$
\begin{aligned}
\mathrm{Y}_{2} & =\alpha+\beta_{1} \mathrm{X}_{1}+\beta_{2} \mathrm{X}_{2} \\
& =38,217+0,389 \mathrm{X}_{1}+0,229 \mathrm{X}_{2}
\end{aligned}
$$

The regression equation above can be explained as follows:

$\alpha=$ The constant value $(\alpha)$ shows a positive value of 38.217 , this means that the student achievement value is 38.217 units or $0.38 \%$. Assuming there is no influence and changes from other variables (other variables remain / cateris paribus)

$\beta_{1}=$ The regression coefficient value of the online learning variable shows a positive value of 0.389 , this means that each increase in online learning in statistics is $11 \%$, causing student learning achievement to increase by 0.389 or $38.9 \%$. Assuming there is no influence from other variables (other variables remain / cateris paribus)

$\beta_{2}=$ The regression coefficient value of the teacher-student communication variable shows a positive value of 0.229 . This means that every increase in teacher-student communication in statistics is $1 \%$, causing student achievement to increase by 0.229 or $22.9 \%$. Assuming there is no influence from other variables (other variables remain / cateris paribus)

The results of data analysis regarding the effect of online learning on learning achievement show that the adjusted $\mathrm{R}$ square value is 0.182 . This shows that the ability of online learning variables and teacher and student communication in explaining the learning achievement variable is $18.2 \%$ while the remaining $81.8 \%$ is influenced by other variables not included in the study, for example learning discipline, learning media, teaching methods, curriculum readiness, learning motivation, parental participation, learning environment, school facilities and infrastructure and so on which were not examined in this study.

The table above shows that the test results for the online learning variable (X1) obtained a $\mathrm{t}_{\text {test }}$ of $3.244>\mathrm{t}_{\text {table }}$ of 1.666 and a sig value of $0.002<0.05$, or $\mathrm{t}_{\text {test }}>\mathrm{t}_{\text {table. }}$. It means that $\mathrm{H}_{\mathrm{a}}$ is accepted, or there is an effect of online learning on increasing learning achievement in science learning in State Elementary School of Cilacap Tengah District, Cilacap Regency.

From the overall average of respondents' answers to online learning variables are in the good category. Its indicated that most teachers give good assessments to online learning variables in increasing student learning achievement, and they better the online learning process in schools. So, the increase in learning achievement will also be good. And the overall average of the respondents' answers to the school communication variable is in the good category, which means that most of the teachers give a good assessment that communication in learning between students and teachers is very important, the better the communication created between teachers and students, it will improve learning achievement.

There are several obstacles and solutions in learning online models. According to the explanation above it can be concluded that in online learning a teacher must have readiness both in the readiness of teaching materials, teaching methods and mastery of technology and so students must have good readiness, responsiveness in online communication, mastery of technology and adequate infrastructure.

This research shows that the online learning process for teachers at Cilacap Tengah District of State elementary school, Cilacap Regency is quite good. It can be seen from almost all schools implementing online learning in this pandemic era through various media used, both Whatsapp (WA), learning videos distributed to students, the learning youtube that is shared is in the form 
of a link. Through this online learning, students can access it as a means of learning anywhere and anytime. Online learning that has been going on for about 1 year has had a positive impact on both students and teachers, including expertise in utilizing existing technology that can be optimally studied and developed as an innovative learning tool.

The online learning process makes students enthusiastic because students can watch interesting learning videos from the teacher accompanied by interesting sound effects, songs and pictures, besides that educational games are currently offered as a learning tool for students that is very interesting and makes students not bored to study. This makes teachers challenged to prepare online learning that is attractive to students, facilitates assessment and monitors student academic progress. Teachers are also creative and innovative with the various online learning platforms offered, trying to be able to master and how to apply them to students to improve student learning achievement and improve the thinking skills of technology literate students in the current millennial era.

The results of research on teachers at State elementary school of Cilacap Tengah Subdistrict Cilacap Regency regarding communication between teachers and students there are still teachers who experience this difficulty because the level of students' understanding of the clarity of the material presented by the teacher is still found that not all students absorb well what is meant delivered by the teacher.

The results of this study on online learning variables are in line with research conducted by Sobron et al which states that there is an effect of Online Learning on the learning outcomes of elementary school students' science subjects [9]. Then, Aryaningrum and Pratama argued that there is an effect of E-Learning towards students' learning outcomes [10]. Research by Yusneli Syafari, Maria Montessori (2021) stated that online learning has a significant effect on students' learning motivation and also has a significant effect on students' learning outcomes [11]. It means that the better online learning provided by the teacher, the better the students' learning motivation and learning outcomes.

Gloria Mothibi's explains about E-learning involves utilization of information and communication technology (ICT) to improve and help teaching and learning [12]. The results of the research showed that that ICT has a statistically significant positive impact on e-learning based students' academic achievements. The findings indicate that ICT has a significant positive impact on students' educational overall academic achievements. From the research, it is explained that there is a strong influence and relationship between online learning and student achievement.

The results of this study on communication variables are in line with Fathurrohman [13]). The results of his research showed that interpersonal communication between teachers and students has a positive and significant effect on students' learning achievement. The result of this study is also in line with the research of Al-Madani which explains that there is a good relationship between the effectiveness of effective teachers' communication toward students' achievement[13]. Besides, Fernandes also explains that students agreed that their perception of the teacher is important for them [7]. If a teacher is a good communicator, the students like the teacher and take an interest in the subject[14]. If the teacher is not a good communicator, they consider that teacher incompetent and do not take an interest in the class or the subject [15].

\section{Conclussion}

Teachers gave perception that if they done good assessment of online learning, it would improved the student achievement. The better communication were created between teachers and students, would increased the their student achievement. The result have shown that there is an effect of online learning on increasing learning achievement in science learning in 
Elementary State of Cilacap Tengah District, Cilacap Regency. Later, based on the analysis data indicated that have an effect of teacher and student communication on increasing learning achievement in student learning science at elementary school.

\section{References}

[1] Adhe, K. R. (2018). Pengembangan Media Pembelajaran Daring Mata kuliah Kajian PAUD di Jurusan PG PAUD Fakultas Ilmu Pendidikan Universitas Negeri Surabaya. Journal of Early Childhood Care and Education. 1(1):26.

[2] Bilfaqih Y, Qomarudin MN. Esensi Penyusunan Materi Pembelajaran Daring. Deepublish; 2015 Oct 21.

[3] Ghirardini B. E-learning methodologies: A guide for designing and developing elearning courses. Food and Agriculture Organization of the United Nations; 2011. Anggraeni Astuti dan Leonard (2012) berjudul peran kemampuan komunikasi matematika terhadap prestasi belajar matematika siswa. JurnalFormatif 2(2): 102-110 ISSN: 2088-351X

[4] Mulyana, Deddy. Ilmu Komunikasi: Suatu Pengantar. Cetakan ke 18. Bandung: PT. Remaja Rosdakarya, 2014

[5] Cangara, Hafied. 2015. Pengantar Ilmu Komunikasi. Cetakan Kedua. PT. Raja Grafindo Persada.

[6] Palupi Y. Implementation of Professionalism of Teacher and Formation of Character in Primary School Students. Dinamika Jurnal Ilmiah Pendidikan Dasar. 2016;8

[7] Cyril Fernandes 2019. The Relationship Between Teacher Communication, and Teacher Credibility, Student Motivation, and Academic Achievement in India. CU Commons Citation Ed.D. Dissertations. 281 Concordia University - Portland

[8] bin Zainal Badri KN, Andi HK. Kepentingan Pendidikan Humanistik dalam Pengembangan Psikologi. Dinamika Jurnal Ilmiah Pendidikan Dasar. 2020 Apr 5;12(1):33-43.

[9] Sobron AN, Bayu R. Persepsi siswa dalam studi pengaruh daring learning terhadap minat belajar IPA. SCAFFOLDING: Jurnal Pendidikan Islam Dan Multikulturalisme. 2019 Sep 3;1(2):30-8.

[10] Aryaningrum K, Pratama RE. Penggunaan Internet Multimedia Interaktif Untuk Meningkatan Hasil Belajar Siswa Pada Pembelajaran IPS. HARMONY. 2016;2(2):119.

[11] Syafari Y, Montessori M. Analisis Pembelajaran Daring Terhadap Motivasi Belajar Dan Prestasi Belajar Siswa Dimasa Pandemi Covid-19. Jurnal Basicedu. 2021 Apr 21;5(3):1294-303.

[12] Mothibi G. A Meta-Analysis of the Relationship between E-Learning and Students' Academic Achievement in Higher Education. Journal of Education and Practice. 2015;6(9):6-9.

[13] Fathurrohman I. Pengaruh komunikasi interpersonal guru dengan siswa terhadap perilaku belajar siswa dalam mewujudkan prestasi belajar siswa. Khazanah Akademia. 2018 Jul 2;2(2):13-21. ISSN: 2165-8714

[14] Al-Madani FM. Relationship between Teachers' Effective Communication and Students' Academic Achievement at the Northern Border University. European Journal of Educational Research. 2015;4(2):90-6.

[15] Sucia V. Pengaruh Gaya Komunikasi Guru Terhadap Motivasi Belajar Siswa. Komuniti: Jurnal Komunikasi Dan Teknologi Informasi. 2017 Mar 29;8(5):112-26.p 